Article

\title{
Highly Defective Dark Nano Titanium Dioxide: Preparation via Pulsed Laser Ablation and Application
}

\author{
Elena D. Fakhrutdinova ${ }^{1}$, Anastasiia V. Shabalina ${ }^{1, *}$, Marina A. Gerasimova ${ }^{2}$, \\ Anna L. Nemoykina ${ }^{3}$, Olga V. Vodyankina ${ }^{4}$ and Valery A. Svetlichnyi ${ }^{1, *(C)}$ \\ 1 Laboratory of Advanced Materials and Technology, Tomsk State University, Tomsk 634050, Russia; \\ fakhrutdinovaed@gmail.com \\ 2 Laboratory of Biophotonics, Siberian Federal University, Krasnoyarsk 660041, Russia; marina_2506@mail.ru \\ 3 Laboratory of Biopolymers and Biotechnology, Tomsk State University, Tomsk 634050, Russia; \\ nemoykina@rambler.ru \\ 4 Laboratory of Catalytic Research, Tomsk State University, Tomsk 634050, Russia; vodyankina_o@mail.ru \\ * Correspondence: shabalinaav@gmail.com (A.V.S.); v_svetlichnyi@bk.ru (V.A.S.); \\ Tel.: +7-3822-531-591 (A.V.S.)
}

Received: 10 April 2020; Accepted: 27 April 2020; Published: 28 April 2020

\begin{abstract}
The development of methods to synthesize and study the properties of dark titania is of the utmost interest due to prospects for its use, primarily in photocatalysis when excited by visible light. In this work, the dark titania powder was prepared by pulsed laser ablation (Nd:YAG laser, $1064 \mathrm{~nm}, 7 \mathrm{~ns}$ ) in water and dried in air. To study the changes occurring in the material, the thermal treatment was applied. The structure, composition, and properties of the obtained powders were studied using transmission electron microscopy, low-temperature $\mathrm{N}_{2}$ adsorption/desorption, $\mathrm{X}$-ray diffraction, thermogravimetry/differential scanning calorimetry, X-ray photoelectron, Raman and UV-vis spectroscopies, and photoluminescence methods. The processes occurring in the initial material upon heating were studied. The electronic structure of the semiconductor materials was investigated, and the nature of the defects providing the visible light absorption was revealed. The photocatalytic and antibacterial activities of the materials obtained were also studied. Dark titania obtained via laser ablation in liquid was found to exhibit catalytic activity in the phenol photodegradation process under visible light $(>420 \mathrm{~nm})$ and showed antibacterial activity against Staphylococcus aureus and bacteriostatic effect towards Escherichia coli.
\end{abstract}

Keywords: dark titania; pulsed laser ablation in liquid; defects; calcination; nanopowders; photocatalysis; phenol; antibacterial properties

\section{Introduction}

Titania $\left(\mathrm{TiO}_{2}\right)$ is a multifunctional semiconducting material that has found applications in a wide variety of fields [1,2]. $\mathrm{TiO}_{2}$ has three crystal modifications, namely, anatase, rutile, and brookite [3]. Different non-stoichiometric titania phases can be formed, and the Magneli phases $\mathrm{Ti}_{n} \mathrm{O}_{2 \mathrm{n}-1}$ [4] bring about a great interest. Depending on their structure, the titanium oxides exhibit significantly different properties. Rutile is a rather inert oxide for biological objects and is characterized by rather weak photocatalytic properties towards oxidation of organic compounds. It is also used in cosmetics, food industry, paints and varnishes, etc. [5]. Anatase is more active, features antibacterial properties, and is known as an effective photocatalyst [6,7]. Different titania forms are widely used in biomedicine [8,9].

Normally, titania is a white powder with the band gap energy of $3.0-3.2 \mathrm{eV}$, and it does not absorb light in the visible range [3] that limits its use in photocatalysis. To increase the effectiveness and widen 
the spectral range of its photocatalytic activity, doping [10-12], core@shell structures' formation [13], decoration [14], and the formation of complex composite/hybrid oxides [15,16] are considered.

Nowadays, "dark" titania is also of great interest. The reduction can change the color of the initially white oxide. Thus, in Reference [17], polycrystalline titania in a reducing media changed its color from white to yellow, then to brown, and finally became blue-black. The black color is due to the presence of the oxygen vacancies of different types, $\mathrm{Ti}^{3+}$ and $\mathrm{Ti}^{4+}$ interstitial ions, and $\mathrm{Ti}-\mathrm{H}$ bonds [18]. Thus, the disorder of the titania lattice plays a significant role in the formation of black $\mathrm{TiO}_{2}$. Structural defects lead to the appearance of additional energy levels in the band gap that is a key factor determining the optical and photocatalytic activity of the materials. Dark titanium dioxide was first obtained in 2011 by heating white $\mathrm{TiO}_{2}$ at $200{ }^{\circ} \mathrm{C}$ and $\mathrm{H}_{2}$ pressure of 20.0 bar [19]. To date, there are a number of publications devoted to the preparation and study of black titanium dioxide, including several reviews [20-22]. To synthesize black $\mathrm{TiO}_{2}$, a number of methods were proposed, including hydrogenation of white titanium dioxide at high and low pressures [21,22], treatment with hydrogen plasma [23], electrochemical and chemical reduction [23,24], and laser irradiation [20,25]. Of great interest is the synthesis of dark oxide from a titanium metal target by pulsed laser ablation in a liquid (LAL).

The high-energy nonequilibrium LAL method is currently used to obtain a wide range of nanoparticles (NPs) [26-29] and for surface structuring [30,31]. The LAL also allows for the production colloids of dark titanium oxide. To date, many publications have been devoted to the ablation of metallic titanium, e.g., [32-45]. Nevertheless, the studies of titanium LAL and the resulting nanostructures continue to attract great interest. This is due to the wide variability of the method depending on the radiation characteristics, other parameters of the ablation process, and the composition of the solution. By varying the radiation characteristics, the reaction medium, and other experimental parameters, the particles of various sizes, stoichiometry, defect concentrations, and crystal structures can be obtained from a metal target. Even under rather similar experimental conditions, it is possible to obtain titanium dioxide NPs with various properties. Thus, the LAL of Ti in water by the radiation of a Nd:YAG laser $(1064 \mathrm{~nm})$ with varying experimental parameters allows for obtaining the crystal structure changes (amorphous, anatase, brookite, rutile) and particles with various defects and non-stoichiometric composition [32-36]. The use of shorter pulses (pico-sec, femto-sec) and wavelengths further diversifies the size, morphology, and structure of the NPs obtained [37,38]. The processes of secondary interaction play an important role. This was confirmed by experiments on the additional laser irradiation of colloids $[39,40]$. In addition, the properties of the powders obtained by drying the colloids synthesized by LAL were poorly studied.

The present work aims to study the morphology, structure, and optical properties of nanopowders obtained by drying and further thermal treatment of dark titanium oxide colloids synthesized by LAL of metal titanium in water. The photocatalytic and antibacterial properties of the obtained powders are also studied.

\section{Materials and Methods}

\subsection{Synthesis of the Materials}

Initial $\mathrm{TiO}_{2}$ nanopowder was prepared according to the following procedure. First, the colloidal solution was obtained by pulsed laser ablation in liquid of titania target $(99.9 \%)$. The Nd:YAG laser LS2131M-20, LOTIS TII (Minsk, Belarus) was used for the LAL. The ablation was carried out in a $100-\mathrm{mL}$ cylindrical reactor for $3 \mathrm{~h}$. Then, the solution was dried in air at $60^{\circ} \mathrm{C}$. The initial sample was annealed in the temperature range of $200-1000{ }^{\circ} \mathrm{C}$. Detailed equipment and the experiment on the preparation of nanopowders were described in [26,46] and Supplementary Materials.

The obtained samples were denoted as $\mathrm{TiO}_{2}$ ini, $\mathrm{TiO}_{2} \_200, \mathrm{TiO}_{2} \_400, \mathrm{TiO}_{2} \_600, \mathrm{TiO}_{2} \_800$, and $\mathrm{TiO}_{2} 1000$. 


\subsection{Characterization of the Materials}

The microstructure of the materials was studied using the transmission electron microscope (TEM) HT-7700, Hitachi (Tokyo, Japan). The scanning electron microscopic (SEM) study was carried out on Vega 3H, Tescan (Brno, Czech Republic). Specific surface and pore sizes were determined using low-temperature $\mathrm{N}_{2}$ adsorption/desorption according to the BET method on the TriStar II 3020, Micromeritics (Norcross, GA, USA). Prior to the measurements, the samples were degassed under vacuum $\left(10^{-2} \mathrm{Torr}\right)$ at $200{ }^{\circ} \mathrm{C}$ for $2 \mathrm{~h}\left(\mathrm{TiO}_{2}\right.$ ini sample was degassed at room temperature). Pore size distribution and porosity were calculated from the desorption isotherms by BJH method (Barrett-Joyner-Halenda).

The X-ray diffraction (XRD) method was used to study the phase composition and average regions of coherent scattering of the powder samples. A Shimadzu XRD 6000 (Kyoto, Japan) diffractometer was used to record the diffraction patterns. The phase composition was identified using the PDF-4 database. The phase contents were calculated using the PowderCell 2.4 software complex (Federal Institute for Materials Research and Testing, Berlin, Germany).

Thermal analysis in the region of $25-1000{ }^{\circ} \mathrm{C}$ was performed using Netzsch STA 449 F1 Jupiter ${ }^{\circledR}$ (Selb, Germany) with a rate of $10^{\circ} / \mathrm{min}$ under dry air flow with the rate of $50 \mathrm{~mL} / \mathrm{min}$. The samples were placed in alundum $\left(\mathrm{Al}_{2} \mathrm{O}_{3}\right)$ crucibles.

Raman spectra were recorded using the Raman microscope InVia, Renishaw (Wotton-under-Edge, $\mathrm{UK}$ ), with laser excitation at a wavelength of $785 \mathrm{~nm}$ in the range of $100-1000 \mathrm{~cm}^{-1}$ at a power $<1 \mathrm{~mW}$ to avoid sample changing during the analysis.

X-ray photoelectron spectroscopy (XPS) data were obtained using X-ray photoelectron spectrometers KRATOS ES 300, Kratos Analytical (Manchester, UK) with a MgK $\alpha$ source.

The UV-Vis absorption spectra $(230-800 \mathrm{~nm})$ of the powders were collected using spectrophotometer Cary 100SCAN, Varian (Belrose NSW, Australia) equipped with the accessory DRA-CA-30I, Labsphere (North Sutton, NH, USA). The band gap was calculated from the diffuse reflection spectra using the Tauc method for indirect semiconductors [47]. The photoluminescence (PL) spectra (280-750 nm) of the powder were recorded on a Fluorolog 3-22 spectrofluorometer, Horiba, Jobin Yvon (Edison, NJ, USA).

\subsection{Photocatalytic and Antibacterial Activity Studies}

The photocatalytic activity of the materials was assessed based on phenol degradation by visible light. Metal-halogen lamp Master Colour CDM-TD 70W/942, Philips (Hamburg, Germany), with the cut-off filter YG11 (410 nm) (Figure S1) was used. A portion of $50 \mathrm{mg}$ of the powder under study was dispersed in $50 \mathrm{~mL}$ of phenol solution in water $\left(5 \times 10^{-5} \mathrm{M}\right)$. Prior to the photocatalytic experiment, the dark stage was performed for $1 \mathrm{~h}$ to reach the sorption equilibrium. After this, the irradiation was carried out for $1 \mathrm{~h}$ at a constant stirring by a magnet stirrer. The luminosity on the surface of the solution was $66 \mathrm{klx}$ (direct sunlight is characterized with 30-120 klx).

Photodegradation and sorption values were calculated based on the phenol concentration decrease. The phenol concentration was determined using fluorimetry from the change in the phenol luminescence intensity at a wavelength of $300 \mathrm{~nm}$ using a CM2203 spectrofluorometer, SOLAR (Minsk, Belarus). The phenol concentration calibration was preliminarily performed. Changes in the absorption spectra of the solutions were monitored photometrically with a Cary 100SCAN spectrophotometer. The particles were removed from the solution via ultracentrifugation by centrifuge Allegra 64R, Beckman Coulter (Brea, CA, USA) for $30 \mathrm{~min}$ at 20,000 rpm.

The antibacterial activity of the dark titania was tested over two bacteria, namely, gram-positive Staphylococcus aureus (S. aureus, test strain ATCC 25923) and gram-negative Escherichia coli (E. coli, test strain B-6954, Russian Collection of Microorganisms) according to the standard ISO 20743:2013 [48]. The experimental conditions and the procedure of the antibacterial activity measurement are described in detail in our previous work [46]. The NPs from the initial colloid of dark titania were precipitated onto a cotton fabric $120 \mathrm{~g} / \mathrm{m}^{2}$ TexLine. The values of antibacterial activity A were determined as: 


$$
\mathrm{A}=\mathrm{F}-\mathrm{G}
$$

where $\mathrm{F}$ and $\mathrm{G}$ are the growth rates of the control sample and the one loaded with $\mathrm{TiO}_{2} \mathrm{NPs}_{\text {, respectively. }}$

\section{Results and Discussion}

\subsection{Structural Studies}

\subsubsection{Microscopic Data}

The initial sample was obtained via LAL followed by drying in air. Then, it was annealed at different temperatures in the region of $200-1000{ }^{\circ} \mathrm{C}$. The initial powder was dark. After 200 and $400{ }^{\circ} \mathrm{C}$, the color changes to light grey, at $600{ }^{\circ} \mathrm{C}$ it becomes white, and after heating up to 800 or $1000{ }^{\circ} \mathrm{C}$, the sample is light yellow. To reveal the structural changes of the material during the thermal treatment, the microscopic studies were applied. Figure 1 shows the TEM images of the materials obtained via LAL and subsequent thermal treatment.

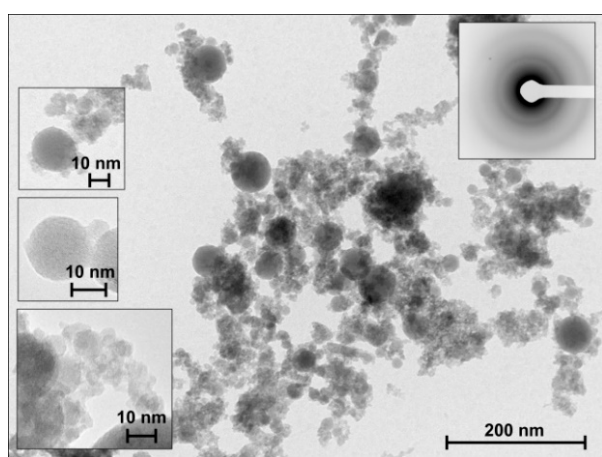

(a)

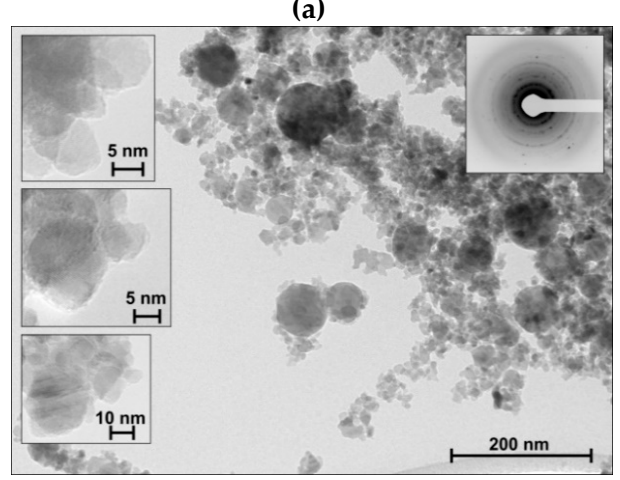

(c)

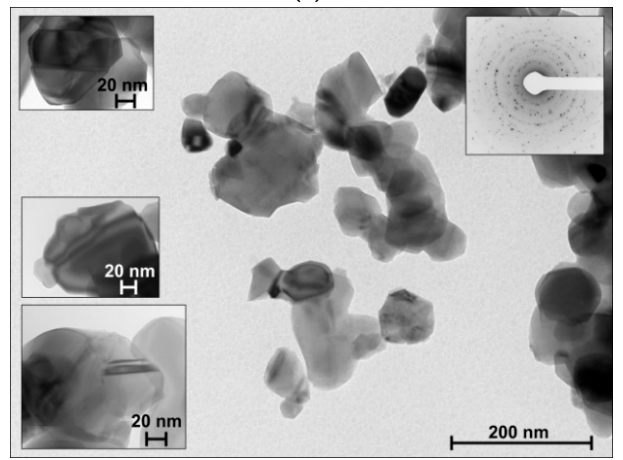

(e)

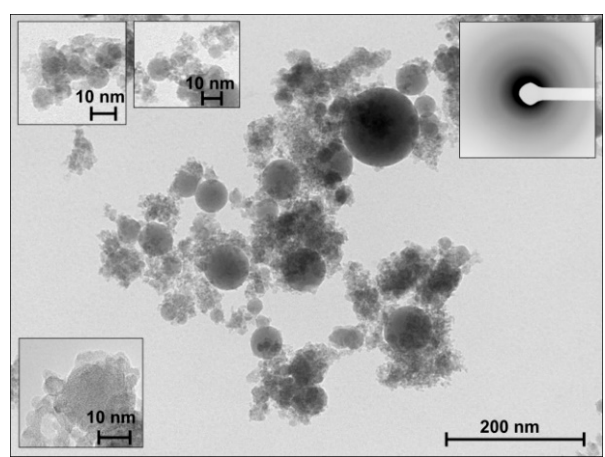

(b)

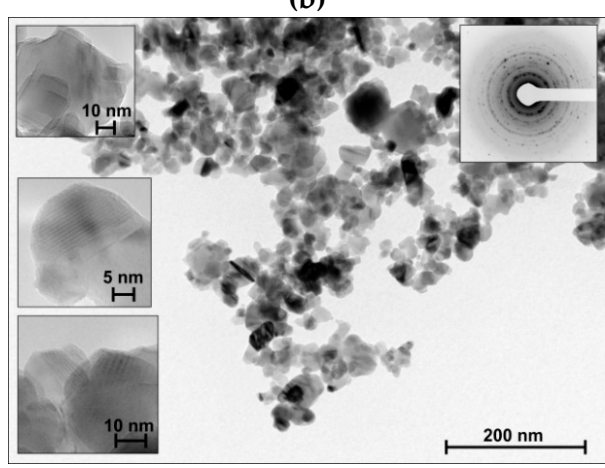

(d)

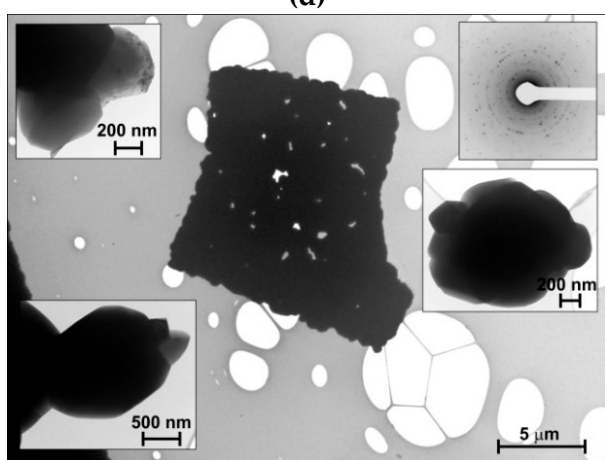

(f)

Figure 1. TEM data for the materials: (a) $\mathrm{TiO}_{2} \_$ini, (b) $\mathrm{TiO}_{2} \_200$, (c) $\mathrm{TiO}_{2} \_400$, (d) $\mathrm{TiO}_{2} \_600$, (e) $\mathrm{TiO}_{2} \_800$, (f) $\mathrm{TiO}_{2}$ 1000. Right top corner insets: Selected area electron diffraction (SAED) data. 
The as-prepared sample (Figure 1a) comprises small spherical particles with sizes of $\sim 5-10 \mathrm{~nm}$, and larger particles of $80 \mathrm{~nm}$. Such a bimodal size distribution is quite characteristic for the NPs obtained via LAL [39,41]. This is due to the specific features of the particle formation mechanism under non-equilibrium conditions when the laser beam interacts with the solid target in the liquid media [28].

Thermal treatment changes the size and shape of the particles. The size increases due to sintering. The spheres coalesce to form agglomerates of the irregularly shaped particles. Starting with the $\mathrm{TiO}_{2} 400$ sample, the particles become facetted. According to the SAED data, the crystallinity increases; $\mathrm{TiO}_{2}$ ini (Figure 1a) and $\mathrm{TiO}_{2} 200$ (Figure 1b) samples exhibit amorphous halos, but $\mathrm{TiO}_{2} 400$ (Figure 1c) and other samples demonstrate the SAED characteristics of polycrystallites. After $800{ }^{\circ} \mathrm{C}$ (Figure 1e,f), the particles lose individual boundaries to yield quite dense large crystalline objects. The $\mathrm{TiO}_{2}{ }_{1} 1000$ sample contains individual large flat agglomerates up to $10 \mu \mathrm{m}$ in size consisting of fused particles (Figure 1f).

\subsubsection{Textural Characteristics}

Figure S2 and Table 1 show the results on the specific surface area and porosity. It is noteworthy that the isotherms for the initial sample and the materials after the thermal treatment up to $600{ }^{\circ} \mathrm{C}$ are of the same type. These samples also demonstrate similar porous structures. Since the pores in the samples are formed by the voids between the particles, the total porosity directly depends on their size and shape. Hysteresis loops at lower relative pressures (from 0.50 to 0.99 ) indicate the mesoporous structure of the samples $\mathrm{TiO}_{2} \_\mathrm{ini}, \mathrm{TiO}_{2} 200, \mathrm{TiO}_{2} \_400$, and $\mathrm{TiO}_{2-} 600$. The pore size distribution for these samples is relatively narrow. The initial titania sample exhibits a pronounced single peak that is located at $7.5 \mathrm{~nm}$ and shifts as the temperature of the thermal treatment increases. The sample $\mathrm{TiO}_{2} 800$ shows the matching of the adsorption and desorption isotherms indicating the absence of pores in the sample. Such isotherms cannot be registered for the $\mathrm{TiO}_{2} \_1000$ sample.

Table 1. Nanoparticles' (NPs') size, BET, and X-ray diffraction (XRD) data for the samples.

\begin{tabular}{|c|c|c|c|c|c|c|}
\hline \multirow{2}{*}{ Sample } & \multirow{2}{*}{$\begin{array}{l}\text { Average Size }(\mathrm{nm}) \\
\text { from TEM Data }\end{array}$} & \multirow{2}{*}{$\mathrm{S}_{\mathrm{BET}}\left(\mathrm{m}^{2} / \mathrm{g}\right)$} & \multirow{2}{*}{$\begin{array}{c}V_{\text {pore }} \\
\left(\mathrm{cm}^{3} / \mathrm{g}\right)\end{array}$} & \multicolumn{2}{|c|}{ Phase Composition (\%) } & \multirow{2}{*}{$\Delta \mathrm{d} / \mathrm{d} \times 10^{-3}$} \\
\hline & & & & Anatase & Rutile & \\
\hline $\mathrm{TiO}_{2 \_ \text {ini }}$ & 10 & $227 \pm 23$ & $0.41 \pm 0.02$ & - & - & - \\
\hline $\mathrm{TiO}_{2 \_} 200$ & 14 & $124 \pm 12$ & $0.37 \pm 0.02$ & - & - & - \\
\hline $\mathrm{TiO}_{2} \_400$ & 16 & $86 \pm 9$ & $0.37 \pm 0.02$ & 67 & 33 & 1.5 \\
\hline $\mathrm{TiO}_{2} \_600$ & 34 & $50 \pm 5$ & $0.28 \pm 0.02$ & 62 & 38 & 1.1 \\
\hline $\mathrm{TiO}_{2} \_800$ & 77 & $7 \pm 1$ & $0.06 \pm 0.01$ & 3 & 97 & 0.2 \\
\hline $\mathrm{TiO}_{2} \_1000$ & 400 & $>1$ & - & - & 100 & - \\
\hline
\end{tabular}

Specific surface area and pore volume values were calculated from the desorption isotherms obtained (Table 1). The initial sample demonstrates the largest $\mathrm{S}_{\mathrm{BET}}$ of $227 \mathrm{~m}^{2} / \mathrm{g}$. The specific surface smoothly decreases with the increase in the heating temperature up to $600{ }^{\circ} \mathrm{C}$. A further temperature increase leads to a sharp decline in the specific surface area and porosity. These results are consistent with the TEM data.

Thus, the materials obtained comprise the spherical amorphous particles growing under thermal treatment that increases the crystallinity and decreases the specific surface area and pore volume of the samples.

\subsection{Composition Study}

\subsubsection{XRD Data}

Figure 2 shows the XRD patterns of the samples. The initial material is amorphous that is consistent with the SAED data. After treatment at $200^{\circ} \mathrm{C}$, the first inclusions of the anatase and rutile crystal phases can be observed, even though the sample is still amorphous. After heating at 400 and 
$600{ }^{\circ} \mathrm{C}$, the amorphous part of the samples disappeared completely, and anatase became the major phase (Table 1). A further temperature increase leads to the anatase-to-rutile transition.

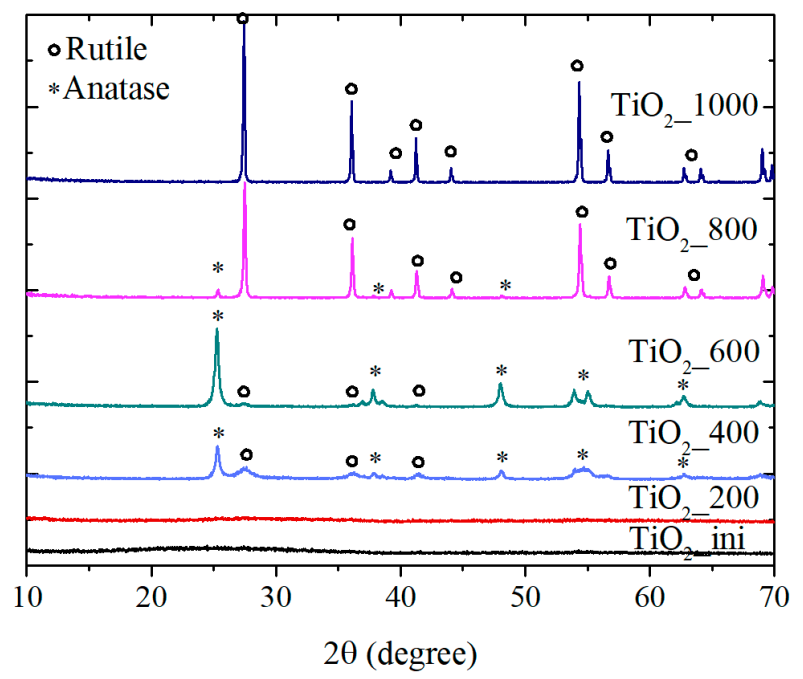

Figure 2. XRD patterns of the samples.

The anatase/rutile phase transition of the bulk material is known to start at $450{ }^{\circ} \mathrm{C}$, and, at $750{ }^{\circ} \mathrm{C}$, the pure rutile phase is formed [49]. In the case under study, the anatase/rutile transition takes place at higher temperatures. Thus, the materials obtained are characterized by the enhanced stability to the thermally induced phase transition. This may be explained by the defects in the surface and sub-surface layers that were formed because of the fast cooling of the substance during the LAL process. These defects seem to act as a hindrance for the fast sintering of the particles that significantly appears only at $800{ }^{\circ} \mathrm{C}$ (see the TEM data, Section 3.1.1., and Table 1).

Thus, the NPs obtained via LAL are amorphous. They crystallize during the thermal treatment, and anatase-to-rutile transition occurs at higher temperatures pointing at higher phase stability of the material. To shed some light on the state and the crystallization process of the initial material, the thermogravimetry/differential scanning calorimetry (TG/DSC) and Raman studies were performed.

\subsubsection{TG/DSC Study}

Figure 3 shows the results of the TG/DSC analysis of the initial LAL-obtained sample.

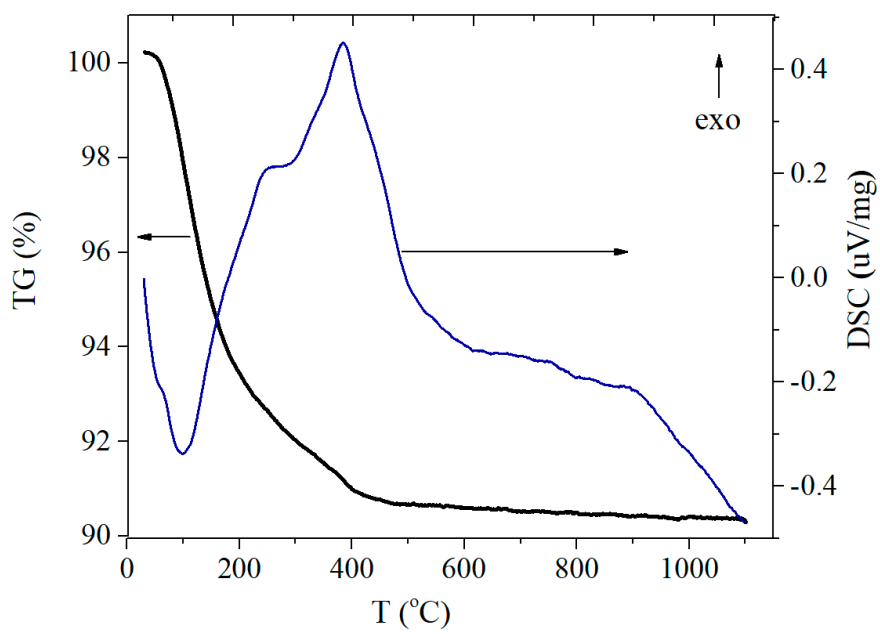

Figure 3. Thermogravimetry/differential scanning calorimetry (TG/DSC) curves of $\mathrm{TiO}_{2}$ ini. 
Two different processes are seen at the DSC curve. The endo-thermal process in the temperature range of $40-200^{\circ} \mathrm{C}$ and the mass loss on the TG curve are associated with the removal of physically adsorbed and chemically bound water. The further slight decrease in mass up to $400{ }^{\circ} \mathrm{C}$ is probably due to the removal of carbonates from the surface of the particles. The exothermic effect on the DSC curve in the temperature range of $250-450{ }^{\circ} \mathrm{C}$ correlates with the crystallization of the initially amorphous $\mathrm{TiO}_{2}$. Above $600{ }^{\circ} \mathrm{C}$, the structural transformation of anatase to rutile begins that refers to the endo-thermal process.

The process of amorphous $\mathrm{TiO}_{2}$ transition into the crystalline one normally occurs at $350-400{ }^{\circ} \mathrm{C}[50,51]$. We believe that such an early crystallization is connected with the small particle size and the specificity of the amorphous material obtained under LAL. For instance, the surface and sub-surface defects mentioned in the previous section might be responsible for it. To receive more information on the structure of the as-obtained $\mathrm{TiO}_{2}$ ini and $\mathrm{TiO}_{2} \_$200, Raman spectroscopy was applied.

\subsubsection{Raman Spectroscopy Studies}

Figure 4 shows the Raman spectra for all samples considered. To study the amorphous state of the initial samples, the spectra for the samples after heating at $100,250,270$, and $300{ }^{\circ} \mathrm{C}$ were additionally recorded. For the powders annealed at temperatures up to $250^{\circ} \mathrm{C}$, three wide weak bands can be observed. The short-wavelength band at $\sim 150 \mathrm{~cm}^{-1}$ belongs to the base mode Eg for anatase. The other bands with the maxima at $\sim 420$ and $600 \mathrm{~cm}^{-1}$ are characteristic for Eg and A1g of rutile, respectively [52,53]. A thermal treatment temperature increase of up to $\sim 270{ }^{\circ} \mathrm{C}$ leads to the formation of anatase structure (Figure 4a). After heating at $300^{\circ} \mathrm{C}$, the Raman spectrum contains only bands at 144 and $196 \mathrm{~cm}^{-1}$ (Eg mode), 398 (B1g), 513 (A1g) and 637 (Eg) characteristic for anatase [52].

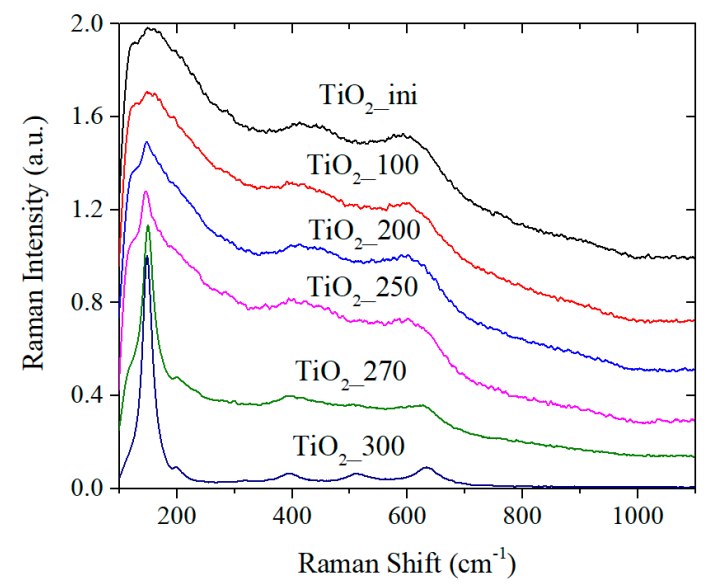

(a)

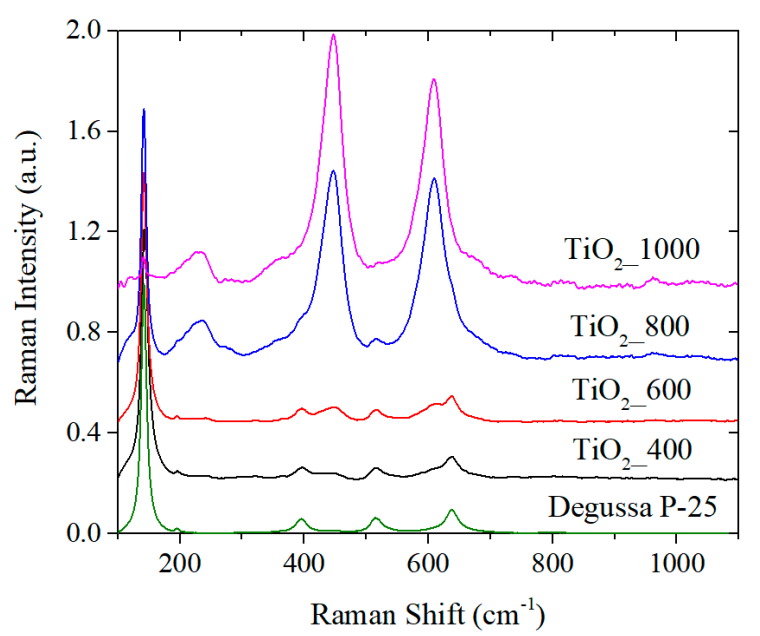

(b)

Figure 4. Raman spectra of the samples annealed under different temperatures: ini-300 ${ }^{\circ} \mathrm{C}(\mathbf{a})$ and $400-1000{ }^{\circ} \mathrm{C}(\mathbf{b})$.

Weak bands of the rutile phase are present in the spectrum for the initial sample. The characteristic anatase short-wavelength band is more intensive but some inhomogeneity (appearing in different intensity and wideness) is observed. The initial sample may consist of a mixture of fine crystallites of anatase and rutile that have only short-range order. Thermal treatment leads to the anatase crystal lattice completion, which is consistent with the DSC and XRD data.

A further temperature increase results in narrowing of the anatase bands (Figure $4 b$ ) that indicates the enlargement of the particles [54]. Then, starting from $600{ }^{\circ} \mathrm{C}$, in addition to the bands belonging to anatase, the rutile vibrational bands $\left(236(\mathrm{~B} 1 \mathrm{~g}), 446(\mathrm{Eg})\right.$ and $\left.610(\mathrm{~A} 1 \mathrm{~g}) \mathrm{cm}^{-1}[55,56]\right)$ appear in the 
spectra. After the calcination at $800^{\circ} \mathrm{C}$, rutile modes dominate in the spectra. Treatment at $1000{ }^{\circ} \mathrm{C}$ results in almost complete disappearance of the anatase modes from the spectra. This data is consistent with the XRD results.

Thus, the NPs of $\mathrm{TiO}_{2}$ obtained via LAL presumably consist of fine anatase and rutile crystallites that form pure anatase and then rutile phases under thermal treatment. The material shows the shifting of the characteristic phase transition temperatures. We believe this is due to the presence of defects in the surface and sub-surface layers. To find out more information on these defects, the XPS and optical studies were performed.

\subsection{Surface States and Functional Properties Studies}

\subsubsection{X-Ray Photoelectron Spectroscopy Data}

According to the XRD, Raman, and DSC data, the initial sample undergoes structural changes upon annealing to $400{ }^{\circ} \mathrm{C}$ associated with the construction of the anatase crystal structure from the X-ray amorphous particles. It is of interest to establish the state of titanium and surface defects associated with the oxygen vacancies during the annealing in this temperature range. Table 2 represents the $\mathrm{O} 1 \mathrm{~s} / \mathrm{Ti} 2 \mathrm{p}$ ratio for the materials. The higher the temperature, the lower the ratio. This is connected with the presence of the $\mathrm{OH}$ groups of the adsorbed water removed from the surface that is consistent with the DSC data (Section 3.2.2.).

Table 2. Data from the XPS spectra.

\begin{tabular}{ccc}
\hline Sample & Carbon Content (\%) & O 1s/Ti 2p Ratio \\
\hline $\mathrm{TiO}_{2 \_ \text {ini }}$ & 17.4 & 2.67 \\
$\mathrm{TiO}_{2 \_} 200$ & 17.2 & 2.58 \\
$\mathrm{TiO}_{2 \_} 400$ & 14.4 & 2.44 \\
\hline
\end{tabular}

The Ti 2p spectra (Figure 5a) contain only a doublet with the binding energy of $458.5 \mathrm{eV}$ (Ti 2p3/2) belonging to the $\mathrm{Ti}^{4+}$ state. Other possible titanium states $\left(\mathrm{Ti}^{3+}, \mathrm{Ti}^{2+}\right)$ are not detected. Thus, it can be concluded that titanium is present in the materials as titania. Figure $5 \mathrm{~b}$ shows the photoemission spectra of $\mathrm{O} 1 \mathrm{~s}$ level. Deconvolution results in two peaks with the binding energies of 529.7-530.2 and $531.9 \mathrm{eV}$. The first of them belongs to the $\mathrm{TiO}_{2}$ lattice oxygen, and the second one is for the oxygen adsorbed on the titania surface.

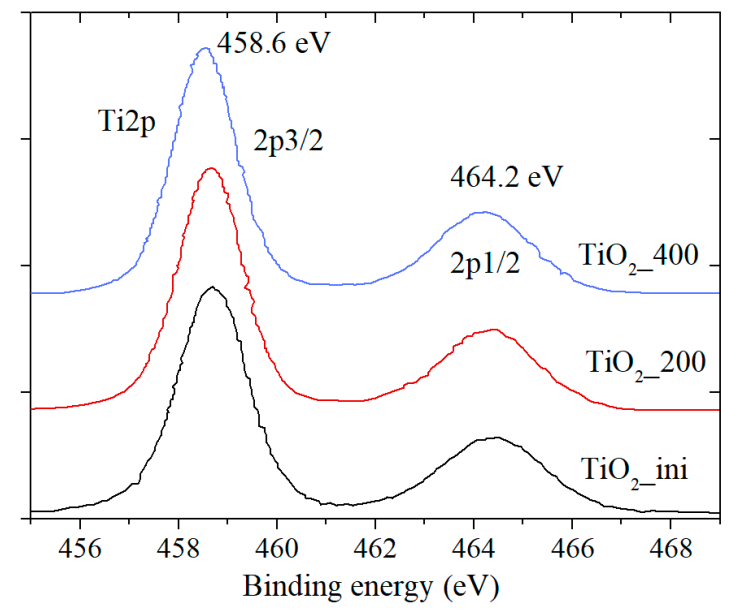

(a)

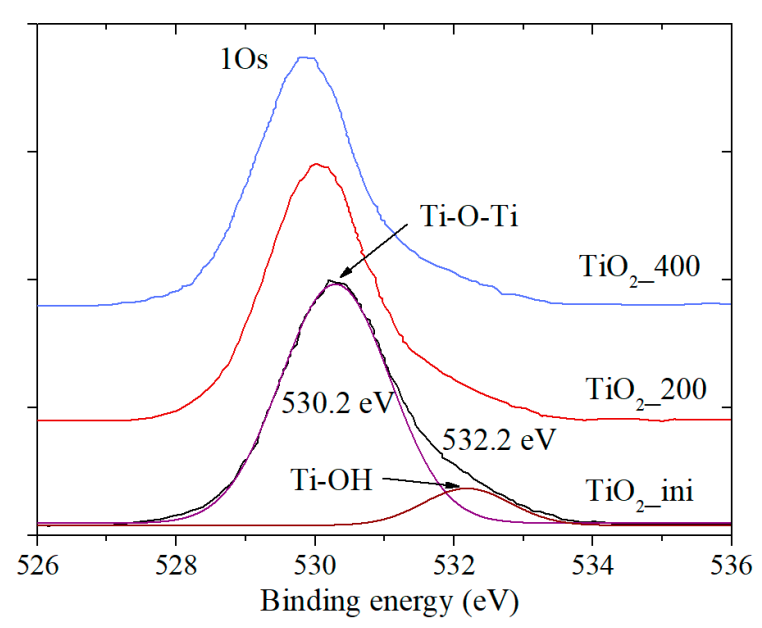

(b)

Figure 5. XPS data for the (a) Ti 2p and (b) O 1s spectra. 
In addition to titanium and oxygen, carbon exists on the surface, and its concentration decreases with the increasing of the annealing temperature (Table 2). This is consistent with the mass loss in TG/DSC data in the range of $200-400{ }^{\circ} \mathrm{C}$. The presence of carbon can be explained by the $\mathrm{CO}_{2}$ sorption from air onto highly active pure particles during drying with the formation of carbonates and bicarbonates on the surface. Similar data on the carbon presence were obtained for other oxides synthesized by LAL [57].

Thus, the XPS method did not detect the specific titanium states $\left(\mathrm{Ti}^{3+}, \mathrm{Ti}^{2+}\right)$ at the surface of the materials obtained. The defects assumed earlier may demonstrate themselves in the optical properties of the materials.

\subsubsection{UV-Visible Absorption Spectra}

Figure 6 represents the UV-Vis absorption spectra of the samples. Besides the UV absorption, all samples have additional absorption in the visible region. The initial sample exhibits the most intensive additional absorption in the long-wavelength region. This is probably due to the defective states of different nature. The amount of these defects decreases during the annealing resulting in the intensity decrease for the additional absorption (curves for the $\mathrm{TiO}_{2} \_400$ and $\mathrm{TiO}_{2} \_600$ samples). However, with the subsequent heating temperature increasing to up to 800 and $1000{ }^{\circ} \mathrm{C}$, this additional absorption reappears. The $\mathrm{TiO}_{2} \_800$ and $\mathrm{TiO}_{2} \_1000$ samples are yellow. Normally, titania powder of any modification is white, and it turns yellow upon heating, turning back to white after cooling. Thus, in the case of the samples annealed at 800 and $1000{ }^{\circ} \mathrm{C}$, the Magneli phase [4] is probably formed due to the crystal lattice restructuring accompanied by the number of oxygen atoms change. This point requires further deeper investigation.

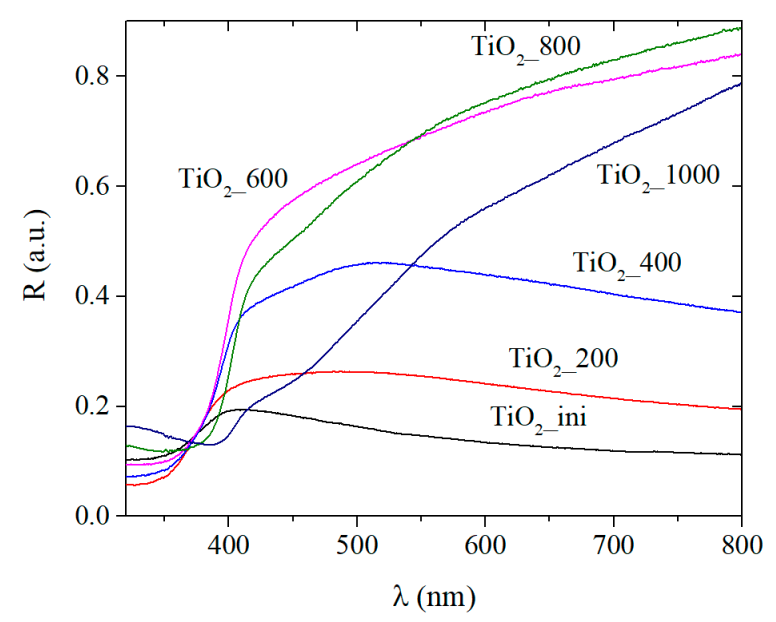

Figure 6. UV-Vis spectra of titania powder.

Table 3 presents the calculated bandgap values from the DRS spectra (Figure S3) for the samples under study. It is known that bulk titania exhibits the $\mathrm{E}_{\mathrm{g}}$ of $3.2 \mathrm{eV}$ for anatase and $3.0 \mathrm{eV}$ for rutile. The samples obtained via LAL and annealing demonstrate the decreased $\mathrm{E}_{\mathrm{g}}$ value. This confirms the presence of energy levels of different defective states in the $\mathrm{TiO}_{2}$ bandgap. These levels lead to the blurring of the boundary of valence and conduction bands and "narrow" the bandgap. 
Table 3. Band gap values for the samples determined at $(F(R) h v)^{1 / 2}$.

\begin{tabular}{cc}
\hline Sample & $\mathbf{E}_{\mathbf{g}}, \mathbf{e V}$ (Tauc) \\
\hline $\mathrm{TiO}_{2}$-ini & 3.12 \\
$\mathrm{TiO}_{2}-200$ & 3.15 \\
$\mathrm{TiO}_{2}-400$ & 3.00 \\
$\mathrm{TiO}_{2}-600$ & 3.05 \\
$\mathrm{TiO}_{2}-800$ & 2.96 \\
$\mathrm{TiO}_{2}-1000$ & 2.80 \\
\hline
\end{tabular}

Thus, the materials obtained exhibit the decreased bandgap energy and defective structure that is a potential advantage for photocatalysis and other applications. To reveal the nature of the defects more carefully, the photoluminescent properties of the materials were studied.

\subsubsection{Photoluminescence Data}

Figure 7 shows the PL spectra of all samples upon excitation either into the exciton absorption band of titanium dioxide, $\lambda_{\mathrm{ex}}=300 \mathrm{~nm}$ (Figure 7a), or into the absorption region of defective states (Figure 6 and Figure S3), $\lambda_{\mathrm{ex}}=405 \mathrm{~nm}$ (Figure $7 \mathrm{~b}$ ). The shapes of the visible spectra upon excitation at 300 and $405 \mathrm{~nm}$ are similar, which indicates a significant contribution to the photoluminescence of structural defects of different nature. To analyze the defects, the published data on the luminescent properties of defects of various types were summarized in Table 4.

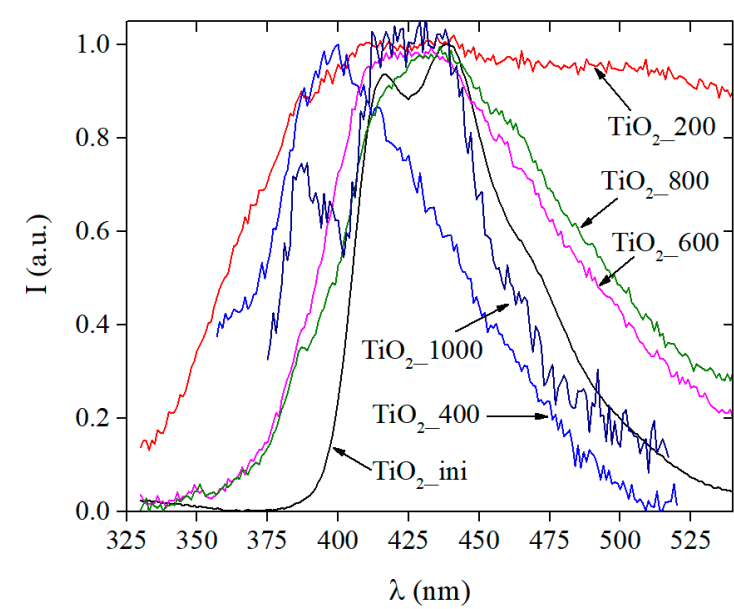

(a)

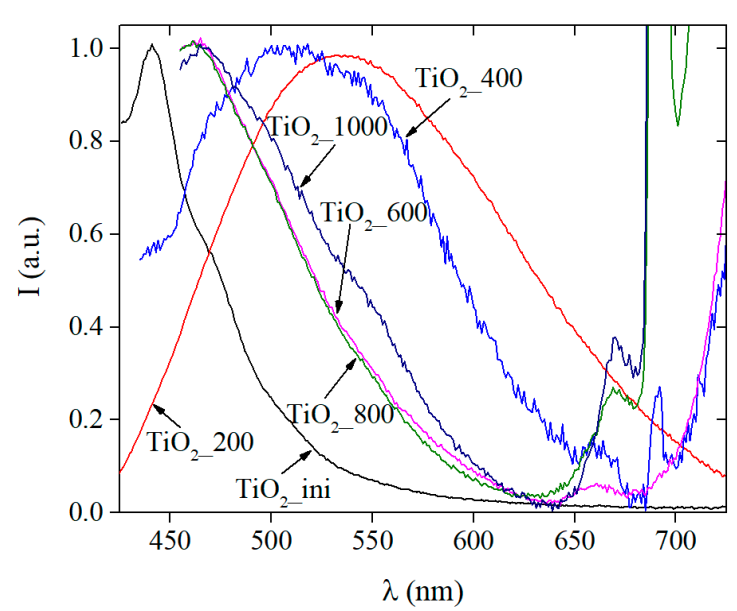

(b)

Figure 7. Photoluminescence spectra of titania powders: $\lambda_{\mathrm{ex}}=300 \mathrm{~nm}(\mathbf{a})$ and $\lambda_{\mathrm{ex}}=405 \mathrm{~nm}(\mathbf{b})$.

Table 4. Interpretation of the PL spectra bands.

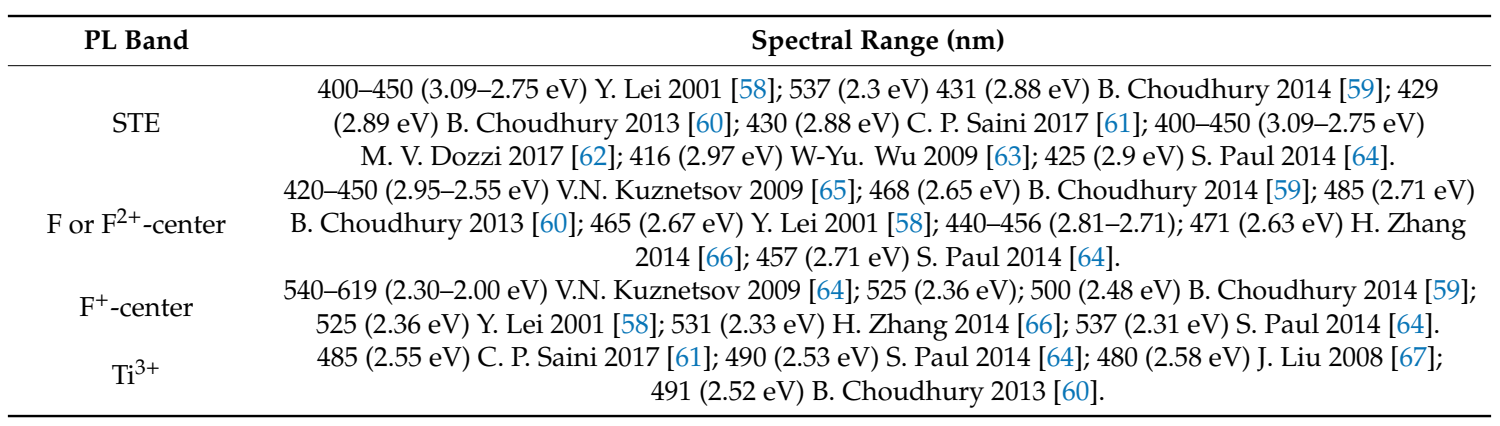

The $\mathrm{TiO}_{2}$ ini sample has a relatively narrow $\mathrm{PL}$ spectrum in the region of $300-500 \mathrm{~nm}$. The most intense band with a maximum at $440 \mathrm{~nm}$ can be attributed to the excitons localized on $\mathrm{TiO}_{6}$ octahedra 
(the so-called self-trapped excitons, STE) [58-64]. The STE states appear when an electron traps a hole in a lattice site. It is believed that the STE states are localized around the oxygen vacancies; therefore, they are in the band gap, but close to the valence band of titanium dioxide [61]. The shoulder at $470 \mathrm{~nm}$ can be attributed to the oxygen vacancies of various types, the so-called $\mathrm{F}$ and $\mathrm{F}^{2+}$ centers $[58-60,64-66]$.

For the $\mathrm{TiO}_{2} 200$ sample, the PL spectrum becomes much wider $(400-700 \mathrm{~nm})$. In the spectrum, the STE states can be distinguished in the region of $400-450 \mathrm{~nm}$. To confirm the presence of the STE states in this sample, we performed a detailed PL experiment with a sequential excitation by different wavelengths (Figure S4). The intense bands in the 450-620 nm region relate to oxygen vacancies of various types ( $\mathrm{F}, \mathrm{F}^{+}$, and $\mathrm{F}^{2+}$ centers): $\mathrm{F}$ and $\mathrm{F}^{2+}$ centers appear in the region of $460-470 \mathrm{~nm}, \mathrm{~F}^{+}$centers are at 520-540 nm [58-60,64-66]. Luminescence in the range of 480-495 $\mathrm{nm}$ can be attributed to charge transfer from $\mathrm{Ti}^{3+}$ or to the oxygen anion in the octahedron $[60,61,64]$ or to the sub-surface oxygen vacancy [67]. The luminescence with the wavelength longer than $600 \mathrm{~nm}$ can be associated with the electronic transitions involving $\mathrm{Ti}^{3+}$ ions located in different positions of the crystal lattice (sites, internodes) and with various types of oxygen vacancies [65]. It might also belong to the intervalent charge transfer between $\mathrm{Ti}^{3+} / \mathrm{Ti}^{4+}$, where the electron is distributed between the cations on the adjacent interstitial and octahedral positions [65,68].

Upon excitation in the region of the defects (Figure 7b), the $\mathrm{TiO}_{2} 400$ sample also receives a wide luminescence profile. However, the bands related to the STE states $(450 \mathrm{~nm})$ are more pronounced in the spectrum, and a luminescence band longer than $650 \mathrm{~nm}$ begins to appear.

The samples annealed at 600,800 , and $1000{ }^{\circ} \mathrm{C}$ are also characterized by the PL in the region of $465-470 \mathrm{~nm}$ and an intense luminescence longer than $650 \mathrm{~nm}$. The intensity of the long-wavelength PL increases with the increasing of the annealing temperature. A decrease in the intensity of the bands in the region of 550-620 nm probably indicates a significant decrease in the amount of the $\mathrm{F}^{+}$centers. The appearance of the intense long-wavelength luminescence correlates with the long-wavelength absorption in the 400-600 $\mathrm{nm}$ region (Figure 6 and Figure S3).

Thus, the nature of the defects present in titania obtained via the LAL was revealed. The majority of the defects are oxygen vacancies. It was also found that under irradiation, these vacancies participate in the formation of the specific STE states. Both these types of defects affect the bandgap value and may play an important role in the material application in photocatalysis, disinfection, etc.

\subsection{Potential Practical Applications}

\subsubsection{Photocatalytic Activity Data}

One of the possible applications of the dark titania obtained via LAL is a photocatalytic decomposition of the organic compounds in water. The challenge is to decompose stable organic molecules like phenol under visible light (e.g., sunlight simulation). Thus, to estimate the photocatalytic potential of the materials synthesized in this work, they were tested in phenol photodegradation in water under visible light. The photoactivity of the materials was compared with the commercial titania (Degussa P25). For all samples, the phenol sorption onto the titania surface was less than $1 \%$. Figure 8 shows the results of phenol decomposition during photocatalysis for $1 \mathrm{~h}$ of exposure. The phenol decomposition was estimated from the decrease in the fluorescence intensity $(\mathrm{fl}=290 \mathrm{~nm})$ upon excitation of the maximum of absorption band $(\mathrm{fl}=275 \mathrm{~nm})$. Figure S5a represents the example of changing in the fluorescence spectra. The estimation of photodecay from the absorption spectra is difficult since upon irradiation the intermediate products are formed that absorb in the same region as phenol (Figure S5b). The absorption bands are typical for transitional phenolic intermediates, i.e., p-benzoquinone $(246 \mathrm{~nm})$, catechol $(270 \mathrm{~nm})$, and hydroquinone $(289 \mathrm{~nm})$ [69]. After prolonged exposure, these products are further decomposed into $\mathrm{CO}_{2}$ and $\mathrm{H}_{2} \mathrm{O}$ [69]. A more detailed study of the phenol photodegradation products will be performed in our further work. 


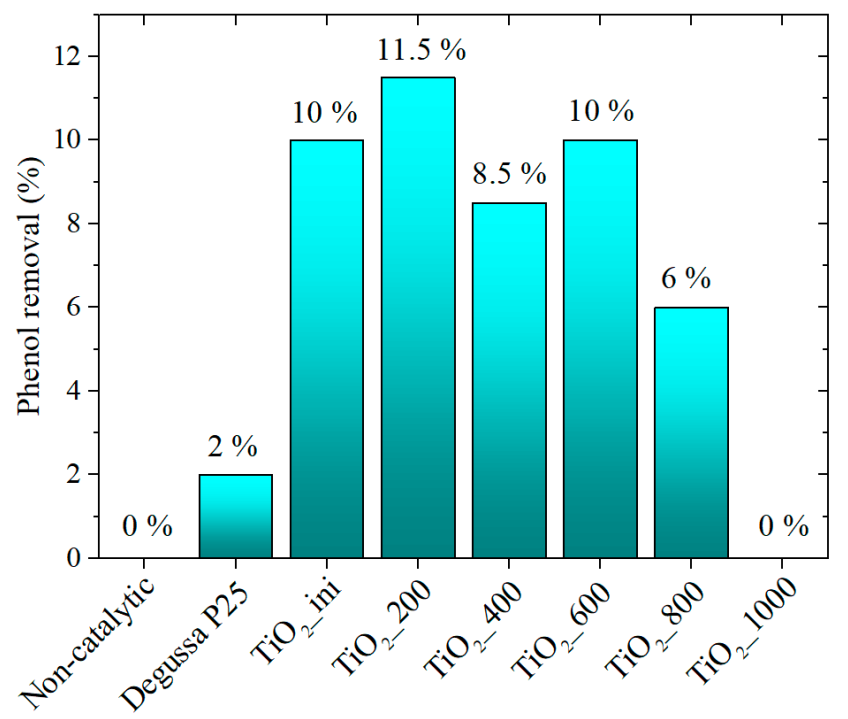

Figure 8. Photodegradation of phenol in water under visible light.

Without any catalyst, phenol does not decompose even under irradiation. For the case of the P25 commercial powder this process takes place but is rather low-intensive. The samples obtained by LAL demonstrate good catalytic activity. The $\mathrm{TiO}_{2} 200$ sample seems to be the most active one. This is due to the high specific surface area, the absorption in the visible region (Figure 6), and the corresponding types of defects (Figure 7). Despite an increase in the rutile content and a decrease in the specific surface area, the samples remain active up to an annealing temperature of $800{ }^{\circ} \mathrm{C}$. This is due to both their absorption properties and the defective structure.

Thus, the materials obtained via LAL and via LAL followed by heating at $200{ }^{\circ} \mathrm{C}$ exhibited photocatalytic activity in the process of phenol degradation under visible light radiation. These materials are promising photocatalysts to be investigated further.

\subsubsection{Antimicrobal Activity Studies}

Titania is widely used as an antimicrobial agent since it is characterized by the resistance to high temperatures, low solubility, high specific surface area, and strong oxidizing properties. The antibacterial activity of the materials obtained in this work was tested. $\mathrm{TiO}_{2}$ ini penetrates well into the cotton fabric when impregnated with a suspension (Figure S6a,b). Table 5 represents the results obtained for the test of the cotton fabric covered with the $\mathrm{TiO}_{2}$ particles of various titania content against gram-positive staphylococcus (S. aureus) and gram-negative coli bacillus (E. coli).

Table 5. Antibacterial activity of dark titania towards S. aureus and E. coli.

\begin{tabular}{|c|c|c|c|}
\hline \multirow{2}{*}{ C on Tissue $\left(\mathrm{mg} / \mathrm{cm}^{2}\right)$} & \multicolumn{2}{|c|}{ The Level of Growth } & \multirow{2}{*}{ Antibacterial Activity A } \\
\hline & Control F & Sample G & \\
\hline \multicolumn{4}{|c|}{ S.aureus (+) } \\
\hline 0.1 & +2.8 & +2.8 & 0 \\
\hline 0.25 & +2.8 & +2.6 & +0.2 \\
\hline 1 & +2.9 & -2.9 & +5.8 \\
\hline \multicolumn{4}{|c|}{$\operatorname{E.coli}(-)$} \\
\hline 1 & +2.1 & +1.0 & +1.1 \\
\hline
\end{tabular}

According to the results obtained, staphylococcus has demonstrated higher sensitivity to the presence of $\mathrm{TiO}_{2}$ than E. coli bacillus, which is consistent with the literature reports [70]. The higher 
the titania concentration, the higher the antibacterial effect towards S. aureus. At the same time, the largest concentration of $\mathrm{TiO}_{2}$ particles exhibited only the bacteriostatic effect on $E$. coli. This variation of titania effect may be connected either with different cell membranes structure of the bacteria under study [71,72] or with the contribution of the electrostatic forces between the positively charged cell walls of $\mathrm{S}$. aureus and negatively charged centers on $\mathrm{TiO}_{2}$ surface (oxygen vacancies). However, the last point requires additional detailed investigation.

Thus, titania samples obtained via LAL exhibit antibacterial and bacteriostatic effects and may be potentially used as a component of the special bandages, antibacterial coatings, etc. It is noteworthy that titania has an additional potential to increase antibacterial activity [73] as well as anti-cancer activity [74] by means of photoactivation.

\section{Conclusions}

Dark titania powder was obtained via the pulsed laser ablation of metallic titanium in water and subsequent drying. The initial material consisting of fine anatase and rutile crystallites $(5-10 \mathrm{~nm})$ is mesoporous with a high specific surface area $\left(227 \mathrm{~m}^{2} / \mathrm{g}\right)$. The $\mathrm{TiO}_{2}$ was found stable under thermal treatment demonstrating the shifts of the phase transitions towards higher temperatures. The material exhibited the intensive visible light absorption due to the additional defect levels in the band gap. For the first time for such materials, the nature of the defects was studied in detail using different methods. The presence of the oxygen vacancies of three types $\left(\mathrm{F}, \mathrm{F}^{+}\right.$, and $\mathrm{F}^{2+}$ centers) and the STE states was revealed by photoluminescence spectroscopy. It was found for the first time that the irradiation of the material with light with wavelength energy exceeding the anatase bandgap energy value activated the STE states. The lifetime of these states was quite long and they appeared in the PL spectra, resulting in a blue shift.

The changes in the dark titania powders during the thermal treatment were studied in detail. The materials obtained consisted of anatase or rutile or their mixture depending on the temperature applied. The structural characteristics of the particles were changed as well varying the heating conditions. It was shown that the annealing temperature increase led to a decrease in the number of defects that affected the color and absorption ability of the samples. The dark titania obtained via LAL exhibited catalytic activity in the phenol photodegradation process under visible light and showed antibacterial activity against $S$. aureus and bacteriostatic effects towards E. coli.

Supplementary Materials: The following are available online at http://www.mdpi.com/1996-1944/13/9/2054/s1, Figure S1: Spectrum of UV-Vis lamp Master Colour CDM-TD $70 W / 942$ (Philips, Amsterdam, The Netherlands) with a cut filter (YG11, Tokyo, Japan), Figure S2: Pore size distribution and nitrogen adsorption-desorption isotherms, Figure S3: UV-vis spectra of powder for their band gap calculation, Figure S4: Photoluminescence spectra of the $\mathrm{TiO}_{2} 200$ sample with the excitation by different wavelengths, while the wavelength was changed in different directions (decreasing or increasing), Figure S5: Fluorescence (a) and absorption (b) spectra of phenol before end after photocatalysis with $\mathrm{TiO}_{2}$ 200, Figure S6: SEM images of cotton (a) and cotton loaded with $0.25 \mathrm{mg} / \mathrm{cm}^{2} \mathrm{TiO}_{2}$ (b) samples.

Author Contributions: Conceptualization, V.A.S.; methodology, O.V.V.; investigation, E.D.F., M.A.G., A.L.N.; writing — original draft preparation, E.D.F.; writing—review and editing, A.V.S. All authors have read and agreed to the published version of the manuscript.

Funding: This research was funded by Russian Science Foundation, grant number 19-73-30026.

Acknowledgments: Characterization was carried out using equipment of the Tomsk Regional Common Use Centre, Tomsk State University. The authors thank M. A. Salaev (Tomsk State University) for language editing.

Conflicts of Interest: The authors declare no conflict of interest.

\section{References}

1. Ong, C.B.; Ng, L.Y.; Mohammad, A.W. A review of ZnO nanoparticles as solar photocatalysts: Synthesis, mechanisms and applications. Renew. Sustain. Energy Rev. 2018, 81, 536-551. [CrossRef]

2. Chen, X.; Mao, S.S. Titanium dioxide nanomaterials: Synthesis, properties, modifications and applications. Chem. Rev. 2007, 107, 2891-2959. [CrossRef] [PubMed] 
3. Hanaor, D.A.H.; Sorrell, C.C. Review of the anatase to rutile phase transformation. J. Mater. Sci. 2011, 46, 855-874. [CrossRef]

4. Xu, B.; Sohn, H.Y.; Mohassab, Y.; Lan, Y. Structures, preparation and applications of titanium suboxides. RSC Adv. 2016, 6, 79706-79722. [CrossRef]

5. Weir, A.; Westerhoff, P.; Fabricius, L.; Hristovski, K.; von Goetz, N. Titanium dioxide nanoparticles in food and personal care products. Environ. Sci. Technol. 2012, 46, 2242-2250. [CrossRef] [PubMed]

6. Fujishima, A.; Rao, T.N.; Tryk, D.A. Titanium dioxide photocatalysis. J. Photochem. Photobiol. C 2000, 1, 1-21. [CrossRef]

7. Zhang, B.; Cao, S.; Du, M.; Ye, X.; Wang, Y.; Ye, J. Titanium Dioxide $\left(\mathrm{TiO}_{2}\right)$ Mesocrystals: Synthesis, Growth Mechanisms and Photocatalytic Properties. Catalysts 2019, 9, 91. [CrossRef]

8. Schneider, S.L.; Lim, H.W. A review of inorganic UV filters zinc oxide and titanium dioxide. Photodermatol. Photoimmunol. Photomed. 2019, 35, 442-446. [CrossRef]

9. Ziental, D.; Czarczynska-Goslinska, B.; Mlynarczyk, D.T.; Glowacka-Sobotta, A.; Stanisz, B.; Goslinski, T.; Sobotta, L. Titanium Dioxide Nanoparticles: Prospects and Applications in Medicine. Nanomaterials 2020, 10, 387. [CrossRef]

10. Shabalina, A.; Fakhrutdinova, E.; Chen, Y.-W.; Lapin, I. Preparation of gold-modified F,N-TiO 2 visible light photocatalysts and their structural features comparative analysis. J. Sol-Gel Sci. Technol. 2015, 75, 617-624. [CrossRef]

11. Liao, C.; Li, Y.; Tjong, S.C. Visible-Light Active Titanium Dioxide Nanomaterials with Bactericidal Properties. Nanomaterials 2020, 10, 124. [CrossRef] [PubMed]

12. Kumaravel, V.; Mathew, S.; Bartlett, J.; Pillai, S.C. Photocatalytic hydrogen production using metal doped $\mathrm{TiO}_{2}$ : A review of recent advances. Appl. Catal. B 2019, 244, 1021-1064. [CrossRef]

13. Chen, T.-M.; Xu, G.-Y.; Ren, H.; Zhang, H.; Tian, Z.-Q.; Li, J.-F. Synthesis of Au@TiO 2 core-shell nanoparticles with tunable structures for plasmon-enhanced photocatalysis. Nanoscale Adv. 2019, 1, 4522-4528. [CrossRef]

14. Mintcheva, N.; Srinivasan, P.; Rayappan, J.B.B.; Kuchmizhak, A.A.; Gurbatov, S.; Kulinich, S.A. Room-temperature gas sensing of laser-modified anatase $\mathrm{TiO}_{2}$ decorated with Au nanoparticles. Appl. Surf. Sci. 2020, 507, 145169. [CrossRef]

15. Mintcheva, N.; Yamaguchi, S.; Kulinich, S.A. Hybrid $\mathrm{TiO}_{2}-\mathrm{ZnO}$ Nanomaterials Prepared Using Laser Ablation in Liquid. Materials 2020, 13, 719. [CrossRef] [PubMed]

16. Yan, Y.; Yu, Y.; Wu, D.; Yang, Y.; Cao, Y. TiO $/$ vanadate $\left(\mathrm{Sr}_{10} \mathrm{~V}_{6} \mathrm{O}_{25}, \mathrm{Ni}_{3} \mathrm{~V}_{2} \mathrm{O}_{8}, \mathrm{Zn}_{2} \mathrm{~V}_{2} \mathrm{O}_{7}\right)$ heterostructured photocatalysts with enhanced photocatalytic activity for photoreduction of $\mathrm{CO}_{2}$ into $\mathrm{CH}_{4}$. Nanoscale 2016, 8, 949-958. [CrossRef] [PubMed]

17. Wang, M.; Nie, B.; Yee, K.-K.; Bian, H.; Lee, C.; Lee, H.K.; Zheng, B.; Lu, J.; Luo, L.; Li, Y.Y. Low-temperature fabrication of brown $\mathrm{TiO}_{2}$ with enhanced photocatalytic activities under visible light. Chem. Commun. 2016, 52, 2988-2991. [CrossRef] [PubMed]

18. Jiang, X.; Zhang, Y.; Jiang, J.; Rong, Y.; Wang, Y.; Wu, Y.; Pan, C. Characterization of Oxygen Vacancy Associates within Hydrogenated $\mathrm{TiO}_{2}$ : A Positron Annihilation Study. J. Phys. Chem. C 2012, 116, 22619-22624. [CrossRef]

19. Chen, X.; Liu, L.; Yu, P.Y.; Mao, S.S. Increasing Solar Absorption for Photocatalysis with Black Hydrogenated Titanium Dioxide Nanocrystals. Science 2011, 331, 746-750. [CrossRef]

20. Ullattil, S.G.; Narendranath, S.B.; Pillai, S.C.; Periyat, P. Black $\mathrm{TiO}_{2}$ Nanomaterials: A Review of Recent Advances. Chem. Eng. J. 2018, 343, 708-736. [CrossRef]

21. Naldoni, A.; Allieta, M.; Santangelo, S.; Marelli, M.; Fabbri, F.; Cappelli, S.; Bianchi, C.L.; Psaro, R.; Dal Santo, V. Effect of Nature and Location of Defects on Bandgap Narrowing in Black $\mathrm{TiO}_{2}$ Nanoparticles. J. Am. Chem. Soc. 2012, 134, 7600-7603. [CrossRef] [PubMed]

22. Han, L.; Ma, Z.; Luo, Z.; Liu, G.; Mac, J.; An, X. Enhanced visible light and photocatalytic performance of $\mathrm{TiO}_{2}$ nanotubes by hydrogenation at lower temperature. RSC Adv. 2016, 6, 6643-6650. [CrossRef]

23. Kang, Q.; Cao, J.; Zhang, Y.; Liu, L.; Xu, H.; Ye, J. Reduced $\mathrm{TiO}_{2}$ nanotube arrays for photoelectrochemical water splitting. J. Mater. Chem. A 2013, 1, 5766-5774. [CrossRef]

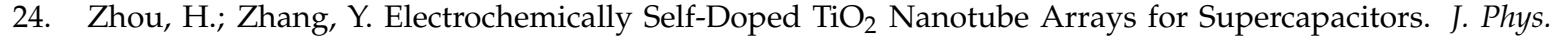
Chem. C 2014, 118, 5626-5636. [CrossRef] 
25. Chen, X.; Zhao, D.; Liu, K.; Wang, C.; Liu, L.; Li, B.; Zhang, Z.; Shen, D. Laser-Modified Black Titanium Oxide Nanospheres and Their Photocatalytic Activities under Visible Light. ACS Appl. Mater. Interfaces 2015, 7, 16070-16077. [CrossRef]

26. Goncharova, D.A.; Kharlamova, T.S.; Lapin, I.N.; Svetlichnyi, V.A. Chemical and Morphological Evolution of Copper NPs Obtained by Pulsed Laser Ablation in Liquid. J. Phys. Chem. C 2019, 123, 21731-21742. [CrossRef]

27. Zhang, D.; Zhang, C.; Liu, J.; Chen, Q.; Zhu, X.; Liang, C. Carbon-Encapsulated Metal/Metal Carbide/Metal Oxide Core-Shell Nanostructures Generated by Laser Ablation of Metals in Organic Solvents. ACS Appl. Nano Mater. 2019, 2, 28-39. [CrossRef]

28. Kanitz, A.; Kalus, M.-R.; Gurevich, E.L.; Ostendorf, A.; Barcikowski, S.; Amans, D. Review on experimental and theoretical investigations of the early stage, femtoseconds to microseconds processes during laser ablation in liquid-phase for the synthesis of colloidal nanoparticles. Plasma Sources Sci. Technol. 2019, 28, 103001. [CrossRef]

29. Reichenberger, S.; Marzun, G.; Muhler, M.; Barcikowski, S. Perspective of Surfactant-free Colloidal Nanoparticles in Heterogeneous Catalysis. ChemCatChem 2019, 11, 1-31. [CrossRef]

30. Kabashin, A.V.; Delaporte, P.; Pereira, A.; Grojo, D.; Torres, R.; Sarnet, T.; Sentis, M. Nanofabrication with Pulsed Lasers. Nanoscale Res. Lett. 2010, 5, 454-463. [CrossRef]

31. Ali, N.; Bashir, S.; Chaudhry, U.-i.-K.; Begum, N.; Rafique, M.S.; Husinsky, W. Effect of liquid environment on the titanium surface modification by laser ablation. Appl. Surf. Sci. 2017, 405, 298-307. [CrossRef]

32. Tian, F.; Sun, J.; Yang, J.; Wu, P.; Wang, H.-L.; Du, X.-W. Preparation and photocatalytic properties of mixed-phase titania nanospheres by laser ablation. Mater. Lett. 2009, 63, 2384-2386. [CrossRef]

33. Zimbone, M.; Buccheri, M.A.; Cacciato, G.; Sanz, R.; Rappazzo, G.; Boninelli, S.; Reitano, R.; Romano, L.; Privitera, V.; Grimaldi, M.G. Photocatalytical and antibacterial activity of $\mathrm{TiO}_{2}$ nanoparticles obtained by laser ablation in water. Appl. Catal. B 2015, 165, 487-494. [CrossRef]

34. Sasaki, K.; Nakano, T.; Soliman, W.; Takada, N. Effect of Pressurization on the Dynamics of a Cavitation Bubble Induced by Liquid-Phase Laser Ablation. Appl. Phys. Express 2009, 2, 046501. [CrossRef]

35. Jasbi, N.E.; Dorranian, D. Effect of aging on the properties of $\mathrm{TiO}_{2}$ nanoparticle. J. Theor. Appl. Phys. 2016, 10, 157-161. [CrossRef]

36. Huang, C.N.; Bow, J.S.; Zheng, Y.; Chen, S.Y.; Ho, N.J.; Shen, P. Nonstoichiometric Titanium Oxides via Pulsed Laser Ablation in Water. Nanoscale Res. Lett. 2010, 5, 972-985. [CrossRef]

37. Semaltianos, N.G.; Logothetidis, S.; Frangis, N.; Tsiaoussis, I.; Perrie, W.; Dearden, G.; Watkins, K.G. Laser ablation in water: A route to synthesize nanoparticles of titanium monoxide. Chem. Phys. Lett. 2010, 496, 113-116. [CrossRef]

38. De Bonis, A.; Galasso, A.; Ibris, N.; Laurita, A.; Santagata, A.; Teghil, R. Rutile microtubes assembly from nanostructures obtained by ultra-short laser ablation of titanium in liquid. Appl. Surf. Sci. 2013, 268, 571-578. [CrossRef]

39. Amin, M.; Tomko, J.; Naddeo, J.J.; Jimenez, R.; Bubb, D.M.; Steiner, M.; Fitz-Gerald, J.; O’Malley, S.M. Laser-assisted synthesis of ultra-small anatase $\mathrm{TiO}_{2}$ nanoparticles. Appl. Surf. Sci. 2015, 348, 30-37. [CrossRef]

40. Guillén, G.G.; Shaji, S.; Palma, M.I.M.; Avellaneda, D.; Castillo, G.A.; Roy, T.K.D.; Gutiérrez, D.I.G.; Krishnan, B. Effects of ablation energy and post-irradiation on the structure and properties of titanium dioxide nanomaterials. Appl. Surf. Sci. 2017, 405, 183-194. [CrossRef]

41. Jafarkhani, P.; Dadras, S.; Torkamany, M.J.; Sabbaghzadeh, J. Synthesis of nanocrystalline titania in pure water by pulsed Nd:YAG laser. Appl. Surf. Sci. 2010, 256, 3817-3821. [CrossRef]

42. Serkov, A.A.; Barmina, E.V.; Shafeev, G.A.; Voronov, V.V. Laser ablation of titanium in liquid in external electric field. Appl. Surf. Sci. 2015, 348, 16-21. [CrossRef]

43. Hong, S.M.; Lee, S.; Jung, H.J.; Yu, Y.; Shin, J.H.; Kwon, K.Y.; Choi, M.Y. Simple Preparation of Anatase $\mathrm{TiO}_{2}$ Nanoparticles via Pulsed Laser Ablation in Liquid. Bull. Korean Chem. Soc. 2013, 34, 279-282. [CrossRef]

44. Chaturvedi, A.; Joshi, M.P.; Mondal, P.; Sinha, A.K.; Srivastava, A.K. Growth of anatase and rutile phase $\mathrm{TiO}_{2}$ nanoparticles using pulsed laser ablation in liquid: Influence of surfactant addition and ablation time variation. Appl. Surf. Sci. 2017, 396, 303-309. [CrossRef]

45. Nath, A.; Laha, S.S.; Khare, A. Effect of focusing conditions on synthesis of titanium oxide nanoparticles via laser ablation in titanium-water interface. Appl. Surf. Sci. 2011, 257, 3118-3122. [CrossRef] 
46. Gavrilenko, E.A.; Goncharova, D.A.; Lapin, I.N.; Nemoykina, A.L.; Svetlichnyi, V.A.; Aljulaih, A.A.; Mintcheva, N.; Kulinich, S.A. Comparative study of physicochemical and antibacterial properties of ZnO nanoparticles prepared by laser ablation of $\mathrm{Zn}$ target in water and air. Materials 2019, 12, 186. [CrossRef]

47. Tauc, J.; Grigorovici, R.; Vancu, A. Optical Properties and Electronic Structure of Amorphous Germanium. Phys. Status Solidi 1966, 15, 627-637. [CrossRef]

48. ISO 20743:2013. Textiles-Determination of Antibacterial Activity of Textile Products, 2nd ed.; ISO: Geneva, Swizerland, 2013.

49. Li, W.; Ni, C.; Lin, H.; Huang, C.P.; Shah, S.I. Size dependence of thermal stability of $\mathrm{TiO}_{2}$ nanoparticles. J. Appl. Phys. 2004, 96, 6662-6668. [CrossRef]

50. Ichinose, H.; Terasaki, M.; Katsuki, H. Synthesis of peroxo-modified anatase sol from peroxo titanic acid solution. J. Ceram. Soc. Jpn. 1996, 104, 715-718. [CrossRef]

51. Ichinose, H.; Terasaki, M.; Katsuki, H. Properties of peroxotitanium acid solution and peroxo-modified anatase sol derived from peroxotitanium hydrate. J. Sol-Gel Sci. Technol. 2001, 22, 33-40. [CrossRef]

52. Gotic, M.; Ivanda, M.; Popovic, S.; Music, S.; Sekulic, A.; Turkovic, A.; Furic, K. Raman investigation of nanosized $\mathrm{TiO}_{2}$. J. Raman Spectrosc. 1997, 28, 555-558. [CrossRef]

53. Golubovic, A.; Scepanovic, M.; Kremenovic, A.; Askrabic, S.; Berec, V.; Dohcevic-Mitrovic, Z.; Popovic, Z.V. Raman study of the variation in anatase structure of $\mathrm{TiO}_{2}$ nanopowders due to the changes of sol-gel synthesis conditions. J. Sol-Gel Sci. Technol. 2009, 49, 311-319. [CrossRef]

54. Gupta, S.K.; Desai, R.; Jha, P.K.; Sahoo, S.; Kirin, D. Titanium dioxide synthesized using titanium chloride: Size effect study using Raman spectroscopy and photoluminescence. J. Raman Spectrosc. 2010, 41, 350-355. [CrossRef]

55. Mazza, T.; Barborini, E.; Piseri, P.; Milani, P. Raman spectroscopy characterization of $\mathrm{TiO}_{2}$ rutile nanocrystals. Phys. Rev. B 2007, 75, 045416. [CrossRef]

56. Lukacevic, I.; Gupta, S.K.; Jha, P.K.; Kirin, D. Lattice dynamics and Raman spectrum of rutile $\mathrm{TiO}_{2}$ : $\mathrm{The}$ role of soft phonon modes in pressure induced phase transition. Mater. Chem. Phys. 2012, 137, 282-289. [CrossRef]

57. Slavinskaya, E.M.; Stadnichenko, A.I.; Muravyov, V.V.; Kardash, T.Y.; Derevyannikova, E.A.; Zaikovskii, V.I.; Stonkus, O.A.; Lapin, I.N.; Svetlichnyi, V.A.; Boronin, A.I. Transformation of $\mathrm{Pt}-\mathrm{CeO}_{2}$ mechanical mixture of pulsed laser-ablated nanoparticles to highly active catalyst for CO oxidation. ChemCatChem 2018, 10, 2232-2247. [CrossRef]

58. Lei, Y.; Zhang, L.D.; Meng, G.W.; Li, G.H.; Zhang, X.Y.; Liang, C.H.; Chen, W.; Wang, S.X. Preparation and photoluminescence of highly ordered $\mathrm{TiO}_{2}$ nanowire arrays. Appl. Phys. Lett. 2001, 78, 1125-1127. [CrossRef]

59. Choudhury, B.; Dey, M.; Choudhury, A. Shallow and deep trap emission and luminescence quenching of $\mathrm{TiO}_{2}$ nanoparticles on Cu doping. Appl. Nanosci. 2014, 4, 499-506. [CrossRef]

60. Choudhury, B.; Choudhury, A. Tailoring luminescence properties of $\mathrm{TiO}_{2}$ nanoparticles by Mn doping. J. Lumin. 2013, 136, 339-346. [CrossRef]

61. Saini, C.P.; Barman, A.; Banerjee, D.; Grynko, O.; Prucnal, S.; Gupta, M.; Phase, D.M.; Sinha, A.K.; Kanjilal, D.; Skorupa, W.; et al. Impact of Self-Trapped Excitons on Blue Photoluminescence in $\mathrm{TiO}_{2}$ Nanorods on Chemically Etched Si Pyramids. J. Phys. Chem. C 2017, 121, 11448-11454. [CrossRef]

62. Dozzi, M.V.; D'Andrea, C.; Ohtani, B.; Valentini, G.; Selli, E. Fluorine-Doped $\mathrm{TiO}_{2}$ Materials: Photocatalytic Activity vs Time-Resolved Photoluminescence. J. Phys. Chem. C 2013, 117, 25586-25595. [CrossRef]

63. Wu, W.-Y.; Chang, Y.-M.; Ting, J.-M. Room-Temperature Synthesis of Single-Crystalline Anatase $\mathrm{TiO}_{2}$ Nanowires. Cryst. Growth Des. 2010, 10, 1646-1651. [CrossRef]

64. Paul, S.; Choudhury, A. Investigation of the optical property and photocatalytic activity of mixed phase nanocrystalline titania. Appl. Nanosci. 2014, 4, 839-847. [CrossRef]

65. Kuznetsov, V.N.; Serpone, N. On the Origin of the Spectral Bands in the Visible Absorption Spectra of Visible-Light-Active $\mathrm{TiO}_{2}$ Specimens Analysis and Assignments. J. Phys. Chem. C 2009, 113, 15110-15123. [CrossRef]

66. Zhang, H.; Zhou, M.; Fu, Q.; Lei, B.; Lin, W.; Guo, H.; Wu, M.; Lei, Y. Observation of defect state in highly ordered titanium dioxide nanotube arrays. Nanotechnology 2014, 25, 275603. [CrossRef]

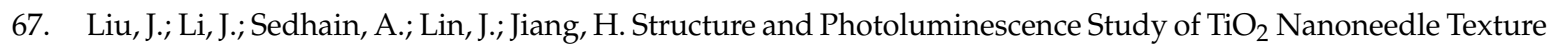
along Vertically Aligned Carbon Nanofiber Arrays. J. Phys. Chem. C 2008, 112, 17127-17132. [CrossRef] 
68. Khomenko, V.M.; Langer, K.; Rager, H.; Fett, A. Electronic absorption by $\mathrm{Ti}^{3+}$ ions and electron delocalization in synthetic blue rutile. Phys. Chem. Miner. 1998, 25, 338-346. [CrossRef]

69. Wang, X.; Wang, F.; Chen, B.; Cheng, K.; Wang, J.; Zhang, J.; Song, H. Promotion of phenol photodecomposition and the corresponding decomposition mechanism over $\mathrm{g}-\mathrm{C}_{3} \mathrm{~N}_{4} / \mathrm{TiO}_{2}$ nanocomposites. Appl. Surf. Sci. 2018, 453, 320-329. [CrossRef]

70. Varnagiris, S.; Urbonavicius, M.; Sakalauskaite, S.; Daugelavicius, R.; Pranevicius, L.; Lelis, M.; Milcius, D. Floating $\mathrm{TiO}_{2}$ photocatalyst for efficient inactivation of E. coli and decomposition of methylene blue solution. Sci. Total Environ. 2020, 720, 137600. [CrossRef]

71. Romaniuk, J.A.H.; Cegelski, L. Bacterial cell wall composition and the influence of antibiotics by cell-wall and whole-cell NMR. Philos. Trans. R. Soc. B 2015, 370, 20150024. [CrossRef]

72. Priyadarshini, S.; Mainal, A.; Sonsudin, F.; Yahya, R.; Alyousef, A.A.; Mohammed, A. Biosynthesis of $\mathrm{TiO}_{2}$ nanoparticles and their superior antibacterial effect against human nosocomial bacterial pathogens. Res. Chem. Intermed. 2020, 46, 1077-1089. [CrossRef]

73. Joost, U.; Juganson, K.; Visnapuu, M.; Mortimer, M.; Kahru, A.; Nõmmiste, E.; Joost, U.; Kisand, V.; Ivask, A. Photocatalytic antibacterial activity of nano- $\mathrm{TiO}_{2}$ (anatase)-based thin films: Effects on Escherichia coli cells and fatty acids. J. Photochem. Photobiol. B 2015, 142, 178-185. [CrossRef] [PubMed]

74. Xu, J.; Sun, Y.; Huang, J.; Chen, C.; Liu, G.; Jiang, Y.; Zhao, Y.; Jiang, Z. Photokilling cancer cells using highly cell-specific antibody- $\mathrm{TiO}_{2}$ bioconjugates and electroporation. Bioelectrochemistry 2007, 71, $217-222$. [CrossRef] [PubMed]

(C) 2020 by the authors. Licensee MDPI, Basel, Switzerland. This article is an open access article distributed under the terms and conditions of the Creative Commons Attribution (CC BY) license (http://creativecommons.org/licenses/by/4.0/). 